\title{
Árangur skurðmeðferðar við Pancoast-lungnakrabbameini á Íslandi
}

\author{
Björn Már Friðriksson ${ }^{1}$ læknanemi, Steinn Jónsson² læknir, Guðrún Nína Óskarsdóttir læknir, Andri Wilberg Orrason læknir, \\ Helgi J. Ísaksson ${ }^{3}$ læknir, Tómas Guðbjartsson ${ }^{1,4}$ læknir
}

\section{ÁGRIP}

Inngangur: Pancoast-æxli eru lungnakrabbamein sem vaxa út frá lungnatoppi í pak fleiðruhols og valda einkennum frá ífarandi vexti í aðlæg líffæri. Tilgangur pessarar rannsóknar var að kanna árangur skurðmeðferðar við Pancoast-æxlum á Íslandi.

Efniviður og aðferðir: Afturskyggn rannsókn á öllum sjúklingum sem gengust undir skurðaðgerð við Pancoast-krabbameini í læknandi tilgangi á Landspítala á árunum 1991-2010. Skráđ voru einkenni sjúklinga, fylgikvillar meðferðar og endurkomutíðni. Æxlin voru stiguð samkvæmt nýju TNM-stigunarkerfi.

Niðurstöður: Tólf sjúklingar gengust undir aðgerð á peim 20 árum sem rannsóknin náđi til, par af 7 á hægra lunga. Algengustu einkenni voru verkur í herðablaði eða öxl ( $n=5)$ og/eða brjóstverkur $(n=3)$, hósti $(n=6) \circ g$ megrun $(n=5)$. Flest æxlanna voru af kirtilfrumugerð $(n=5)$ eða flögupekjugerð $(n=4)$. Meðalstærð æxlanna var $5,9 \mathrm{~cm}$ (bil: 2,8-15) og voru 5 á stigi
IIB og 7 á stigi IIIA. ÆExlin voru fjarlægð með hreinum skurðbrúnum í 10 tilfellum (83\%). Allir sjúklingarnir lifðu aðgerðina af en einn sjúklingur varó fyrir alvarlegum fylgikvilla sem var mikil blæðing í aðgerð. Einn sjúklingur fékk geisla- og lyfjameðferð fyrir aðgerð en 8 fengu geislameðferð eftir aðgerð. Níu sjúklingar greindust síðar með endurkomu sjúkdóms; fjórir með staðbundna endurkomu, fjórir með útbreiddan sjúkdóm og einn með hvort tveggja. Heildarlifun eftir 5 ár var $33 \%$ en miðgildi lifunar var 27,5 mánuðir (bil: 4-181).

Ályktanir: Árangur skurðaðgerða og skammtímahorfur sjúklinga með Pancoast-krabbamein hafa verið góðar hérlendis. Langtímahorfur í pessarri rannsókn voru hins vegar lakari en í nýlegum erlendum rannsóknum og tíðni staðbundinnar endurkomu há. Hugsanleg skýring gæti verið ófullnægjandi stigun fyrir aðgerð og lítil notkun á sampættri geisla- og lyfjameðferð fyrir aðgerð hjá sjúklingum í pessarri rannsókn.
'Læknadeild Háskóla Íslands, 2lungnadeild, 3meinafræðideild ‘ 4hjartaog lungnaskurðdeild Landspítala.

Fyrirspurnir: Tómas Guðbjartsson tomasgud@landspitali.is

Greinin barst 29. mars 2015, sambykkt til birtingar 16. júní 2015.

\section{Inngangur}

Pancoast-æxli eru sjaldgæf tegund af lungnakrabbameinum og í flestum rannsóknum eru pau í kringum $5 \%$ peirra. ${ }^{8,11,26}$ Pau eru nefnd eftir röntgenlækninum Henry Pancoast sem lýsti peim fyrstur árið $1924 .{ }^{15}$ Pancoast-krabbamein eru upprunnin í efsta hluta lungans og vaxa með ífarandi hætti í efsta hluta brjóstveggjarins og aðlæg líffæri. ${ }^{21}$ Pannig eru pau skilgreind í nýjasta TNM-stigunarkerfinu (útgáfa 7) sem T3 eða T4 æxli, en undir pá skilgreiningu falla pau lungnaæxli sem vaxið hafa í nálæg líffæri eins og brjóstvegg, pind eða meginberkju lungans. ${ }^{4}$

Vegna staðsetningar valda Pancoast-æxli oft verk í öxl eða baki vegna ífarandi vaxtar í fleiðru á innanverðu brjóstholi eða taugar í armflækju. ${ }^{3}$ Æxlin geta einnig valdið Horner's heilkenni vegna vaxtar í drifkerfistaugahnoð (sympatic ganglia) brjóstkassans sömu megin og einkennin eru. Pau geta einnig valdið rýrnun á handarvöðvum og bjúg á griplim ef æxlið vex inn í armflækju og neðanviðbeinsbláæð. ${ }^{3}$ Pessi einkenni kallast einu nafni Pancoast-heilkenni.

Meðferð Pancoast-æxla er flókin vegna staðsetningar peirra í brjóstholinu og klínískrar hegðunar. Brottnám æxlis með skurðaðgerð getur verið tæknilega krefjandi, bæði vegna nærliggjandi tauga til griplims og hættu á blæðingu frá æðum í inntaki brjósthols (thoracic inlet). ${ }^{16}$ Áður fyrr fólst læknandi meðferð við Pancoast-krabbameini í geislameðferð og síðar skurðaðgerð, en fimm ára lifun sjúkdómsins var pá aðeins í kringum 30\%. Í dag er mælt með samtvinnaðari geisla- og lyfjameðferð fyrir skurðaðgerð, ${ }^{21}$ og er fimm ára lifun sjúkdómsins allt að $50 \%$ á stærri sjúkrahúsum. ${ }^{12,}{ }^{18}$ Sterkustu forspárpættir lifunar eru
T-stig æxlis, svörun við geisla- og lyfjameðferð og hreinar skurðbrúnir eftir aðgerð. ${ }^{1,9,12,18}$ Um helmingur sjúklinga greinist með endurtekið krabbamein sem oftast eru fjarmeinvörp fremur en staðbundið krabbamein. ${ }^{25}$

Í Læknablaðinu hafa áður birst greinar um árangur blaðnáms, lungnabrottnáms og fleygskurða við lungnakrabbameini hér á landi. Tilgangur pessarar rannsóknar var að kanna árangur skurðmeðferðar við Pancoastæxlum með sérstakri áherslu á skammtímafylgikvilla og langtímalifun sjúklinga.

\section{Efniviður og aðferðir}

Rannsóknin var afturskyggn og náði til allra sjúklinga sem greindust með Pancoast-krabbamein í lungum og gengust undir skurðaðgerð á Landspítala frá 1. janúar 1991 til 31. desember 2010. Aðeins voru tekin með tilfelli par sem skurðaðgerð var beitt í læknandi tilgangi en könnunaraðgerðum (explorative thoracotomy) var sleppt. Öll tilskilin leyfi lágu fyrir áđur en rannsóknin hófst, frá Persónuvernd, Vísindasiðanefnd og framkvæmdastjóra lækninga á Landspítala.

Pancoast-æxli voru skilgreind sem lungnakrabbamein af ekki smáfrumugerð (non small-cell lung cancer, NSCLC) sem uxu út frá lungnatoppi eða efra lungnablaði og paðan út í innri fleiðru (pleura parietale) brjóstkassa eða dýpra í brjóstkassa/aðlæg líffæri, í hæð við fyrsta rif eða ofar. ${ }^{5,21}$ Einkenni Pancoast-heilkennis voru ekki forsenda fyrir greiningu Pancoast-lungnakrabbameins.

Sjúklingar voru fundnir með leit í tveimur aðskildum skrám, annars vegar úr rafrænni aðgerðar- og greiningarskrá Landspítala og hins vegar úr gagna- 


\begin{tabular}{|c|c|c|c|c|c|c|c|c|}
\hline $\begin{array}{l}\text { Númer } \\
\text { sjúklings } \\
\text { (ár) }\end{array}$ & $\begin{array}{l}\text { Aldur/ } \\
\text { kyn }\end{array}$ & Einkenni & $\begin{array}{l}\text { Reykinga- } \\
\text { saga } \\
\text { (pakkaár) }\end{array}$ & Ađrir sjúkdómar & Vefjagerð & $\begin{array}{l}\text { Stærð æxlis } \\
\text { í cm }\end{array}$ & $\begin{array}{l}\text { pTNM } \\
\text { stigun }\end{array}$ & $\begin{array}{l}\text { Ífarandi vöxtur við } \\
\text { greiningu }\end{array}$ \\
\hline $1(1992)$ & $42 / \mathrm{kvk}$ & $\begin{array}{l}\text { Verkur í herðablaði með } \\
\text { leiðni í handlegg }\end{array}$ & 20 & - & Stórfrumugerð & 5,5 & T4NOMO & $\begin{array}{c}\text { Hryggjarbolir/ } \\
\text { armflækja/ } \\
\text { neðanviðbeinsslagæð }\end{array}$ \\
\hline 2 (1994) & $53 / \mathrm{kk}$ & $\begin{array}{c}\text { Brjóstverkur með leiðni í } \\
\text { handlegg }\end{array}$ & 40 & - & Kirtilfrumugerð & 3,2 & T3NOMO & Fleiðra \\
\hline $3(1996)$ & $48 / \mathrm{kvk}$ & $\begin{array}{c}\text { Brjóstverkur með leiðni í } \\
\text { handlegg }\end{array}$ & 33 & - & Kirtilfrumugerð & 3,7 & T3N1M0 & Rif/millirifjavöðvar \\
\hline $4(1997)$ & $52 / \mathrm{kk}$ & Hósti/uppgangur/megrun & 40 & - & Flögupekjugerð & 12,5 & T3N1M0 & Fleiðra \\
\hline 5 (1997) & $57 / \mathrm{kk}$ & $\begin{array}{c}\text { Verkur í herðablaði /hósti/ } \\
\text { uppgangur/mæði/megrun/ } \\
\text { hiti/lungnabólga }\end{array}$ & 50 & $\begin{array}{c}\text { Lungnateppa + } \\
\text { kransæðasjúkdómur }\end{array}$ & Stórfrumugerð & 15 & T3NOMO & Fleiðra \\
\hline 6 (1999) & $84 / \mathrm{kk}$ & Tilviljunargreining & 42 & Hjartsláttartruflun & Kirtilfrumugerð & 8 & T3NOMO & Fleiðra \\
\hline 7 (2004) & $56 / \mathrm{kk}$ & Verkur í öxl & 40 & - & Kirtilfrumugerð & 2,8 & T3NOMO & Fleiðra \\
\hline $8(2005)$ & $69 / \mathrm{kk}$ & Hósti/mæði & 60 & Lungnateppa & Flögupekjugerð & 6,8 & T3N1M0 & Fleiðra \\
\hline 9 (2006) & $62 / \mathrm{kk}$ & Hósti/blóðhósti & 35 & $\begin{array}{l}\text { Lungnateppa + } \\
\text { kransæðasjúkdómur } \\
+ \text { hjartsláttartruflun }\end{array}$ & Flögupekjugerð & 6,7 & T4NOMO & Armflækja \\
\hline $10(2006)$ & $65 / \mathrm{kvk}$ & $\begin{array}{c}\text { Verkur í öxl með leiðni } \\
\text { í handlegg /hósti/ } \\
\text { uppgangur/mæđi/megrun/ } \\
\text { lungnabólga }\end{array}$ & 40 & Lungnateppa & $\begin{array}{c}\text { Blönduð } \\
\text { flögupekju -og } \\
\text { kirtilfrumugerð }\end{array}$ & 5,8 & T3NOMO & Fleiðra \\
\hline $11(2008)$ & $50 / \mathrm{kk}$ & $\begin{array}{l}\text { Brjóstverkur með leiðni } \\
\text { aftur í bak/megrun }\end{array}$ & 42 & - & Flögupekjugerð & 4 & T4NOMO & $\begin{array}{c}\text { Armflækja/ } \\
\text { hryggjarbolir/rifbein }\end{array}$ \\
\hline 12 (2009) & $52 / \mathrm{kk}$ & Verkur í öxl/hósti/mæði & 40 & - & Kirtilfrumugerð & 6 & T4NOMO & $\begin{array}{c}\text { Armflækja/ } \\
\text { neðanviðbeinsslagæð }\end{array}$ \\
\hline
\end{tabular}

grunni rannsóknarstofu Landspítala í meinafræði. Klínískar upplýsingar fengust úr sjúkraskrám og vefjasýni allra sjúklinga voru endurskoðuð af meinafræðingi (H.J.Í.). Skráð var vefjagerð æxlis, gráða, mesta pvermál og staðsetning og hvort skurðbrúnir voru án æxlisvaxtar. Úr sjúkraskrám voru skráđar rúmlega 80 breytur í tölvuforritið Excel, meðal annars hvaða einkenni leiddu til greiningar, tímalengd frá upphafi einkenna til greiningar, legutími í dögum, fylgikvillar aðgerðar, og skurðdauði (dánartíðni innan 30 daga). Tíðni endurkomins krabbameins var könnuð sérstaklega en sjúklingar sem greindust með fjarmeinvörp innan priggja mánaða frá aðgerð voru skilgreindir með útbreiddan sjúkdóm (stig IV) við greiningu. Öll æxlin voru stiguð samkvæmt 7. útgáfu af TNMstigunarkerfi frá 2009 og byggði hún að mestu á upplýsingum eftir aðgerð (pTNM). ${ }^{4}$

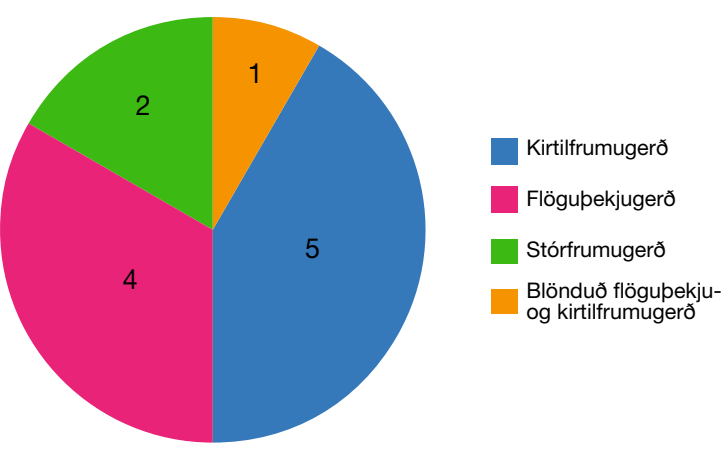

Mynd 1. Vefjagerð 12 sjúklinga sem gengust undir aðgerð við Pancoast-lungnakrabbameini á Îslandi á árunum 1991-2010.
Stigun fyrir aðgerð var ekki stöðluð en alltaf var gerð röntgenmynd af lungum, ísótópaskann af beinum auk tölvusneiðmyndar (TS) af brjóstholi og efri hluta kviðarhols. Í völdum tilvikum var einnig gerð segulómun af brjóstholi og tölvusneiðmynd af höfði. Miðmætisspeglun var framkvæmd fyrir brjóstholsskurð hjá premur sjúklinganna (25\%).

Excel var notað við tölfræðilega úrvinnslu. Upplýsingar um lífshorfur voru fengnar úr Dánarmeinaskrá Landlæknisembættisins og miðuðust útreikningar á lifun við 1. október 2014. Upplýsingar fengust um afdrif allra sjúklinga og var meðaleftirfylgdartími 27,5 mánuðir (bil: 4-181).

\section{Niðurstöठur}

Tólf sjúklingar gengust undir skurðaðgerð vegna Pancoast-æxlis á rannsóknartímabilinu: 9 karlar (75\%) og prjár konur. Yfirlit yfir sjúklinga má sjá í töflu I. Meðalaldur var 57,5 ár og var sá yngsti 42 ára og sá elsti 84 ára. Allir sjúklingarnir höfðu sögu um reykingar, par af voru 10 sem reyktu innan fimm ára fyrir aðgerð. Fjórir sjúklingar höfðu sögu um langvinna lungnateppu og voru tveir peirra einnig með kransæðasjúkdóm. Tveir aðrir sjúklingar höfðu sögu um hjartsláttaróreglu.

Algengustu einkenni voru verkur í herðablaði eða öxl (n=5) og/ eða brjóstverkur ( $n=3)$. Önnur algeng einkenni voru hósti $(n=6)$, oftast með uppgangi en blóðhósti hjá einum, megrun (n=5), mæði $(n=4)$, og hiti $(n=1)$. Einn sjúklingur var án einkenna lungnakrabbameins og greindist fyrir tilviljun á röntgenmynd af lungum. Enginn sjúklinganna reyndist hafa Horners-heilkenni, rýrnun á handarvöðvum eða bjúg á griplimum. 
Tafla I. framhald

\begin{tabular}{|c|c|c|c|c|c|c|c|}
\hline $\begin{array}{l}\text { Númer } \\
\text { sjúklings } \\
\text { (ár) }\end{array}$ & $\begin{array}{l}\text { Meðferð fyrir } \\
\text { aðgerð }\end{array}$ & Tegund aðgerðar & Fylgikvillar aðgerðar & $\begin{array}{c}\text { Fríar } \\
\text { skurðbrúnir }\end{array}$ & Meðferð eftir aðgerð & $\begin{array}{l}\text { Endurkoma } \\
\text { æxlis }\end{array}$ & $\begin{array}{l}\text { Lifun (hrá) í } \\
\text { mánuðum }\end{array}$ \\
\hline 1 (1992) & - & Blaðnám & $\begin{array}{l}\text { Lömun á } \\
\text { raddbandataug/ } \\
\text { loftleki }\end{array}$ & Já & Geislameðferð & $\begin{array}{l}\text { Hengja } \\
\text { ásgarnar }\end{array}$ & 181 \\
\hline 2 (1994) & - & Blađnám & Loftleki & Nei (R2) & Geislameðferð & $\begin{array}{l}\text { (Beinsarkmein } \\
\text { vegna geisla) }\end{array}$ & 116 \\
\hline 3 (1996) & - & Blađnám & Kraftminnkun í öxl & Já & Geislameðferð & $\begin{array}{c}\text { Bein/eitlar/hitt } \\
\text { lungað }\end{array}$ & 31 \\
\hline $4(1997)$ & - & Blaơnám & Loftleki & Já & Geislameðferð & Staðbundin & 24 \\
\hline $5(1997)$ & - & Blađ̃nám & Loftleki & Já & Geislameðferð & Heili & 8 \\
\hline 6 (1999) & - & Blađ̃nám & - & Já & Geislameðferð & - & 58 \\
\hline 7 (2004) & - & Blađnám & - & Já & Geislameðferð & $\begin{array}{l}\text { Staðbundin/ } \\
\text { bein/heili }\end{array}$ & 22 \\
\hline 8 (2005) & - & Blađnám & Loftleki & Já & - & Staðbundin & 12 \\
\hline 9 (2006) & - & Lungnabrottnám & Lungnabólga & Nei (R2) & - & Staðbundin & 16 \\
\hline $10(2006)$ & - & Lungnabrottnám & $\begin{array}{l}\text { Lungnabrottnám } \\
\text { v. blæðingar/ } \\
\text { lungnabólga }\end{array}$ & Já & - & Hnútur á baki & 4 \\
\hline $11(2008)$ & $\begin{array}{c}\text { Geisla - og } \\
\text { lyfjameðferð }\end{array}$ & Blaðnám & - & Já & Geisla - og lyfjameðferð & - & 79 \\
\hline 12 (2009) & - & Blaðnám & - & Já & $\begin{array}{l}\text { Lyfjameðferð og síðan } \\
\text { geislameðferð eftir } \\
\text { endurkomu } 5 \text { mán. síðar }\end{array}$ & Staðbundin & 68 \\
\hline
\end{tabular}

*R2: Ekki tókst að fjarlægja allan æxlisvefinn í aðgerðinni.

Vefjafræði æxlanna er sýnd á mynd 1 og voru öll æxlin af öðrum vefjagerðum en smáfrumukrabbamein (NSCLC). Flest voru af kirtilfrumu- $(n=5)$ eða flögupekjugerð $(n=4)$ en tvö æxlanna voru af stórfrumugerð og eitt var blandað kirtilfrumu- og flögupekjuæxli. Fimm æxlanna voru meðalvel proskuð, 5 voru illa proskuð og eitt óproskað. Í einu tilviki var ekki hægt að meta gráðu æxlis pví geisla- og lyfjameðferð hafði verið gefin fyrir aðgerð. Mesta pvermál æxlanna var 5,9 cm að meðaltali (bil: 2,8-15). Átta æxli voru á stigi T3, par af voru prjú með eitilmeinvörp í lungnaporti (hilus) (N1) en hin 5 voru án eitilmeinvarpa (N0). Fjögur æxli voru á stigi T4, öll án eitilmeinvarpa (N0). Enginn sjúklinganna var með fjarmeinvörp við greiningu (stig IV).

Alls gengust 10 sjúklingar undir blaðnám, en tveir undir lungnabrottnám. Meðaltal aðgerðartíma var 128 mínútur (bil: 90260). Heildartíðni minniháttar fylgikvilla var $75 \%$ og var oftast um viðvarandi loftleka $(n=5)$ eða lungnabólgu $(n=2)$ að ræða. Eini alvarlegi fylgikvillinn var mikil blæðing í aðgerð (>1 L) sem olli pví að breyta purfti blaðnámi í lungnabrottnám. Legutími eftir aðgerð var að meðaltali 12,5 dagar og 10 dagar að miðgildi (bil: 4-32). Enginn sjúklingur lést innan 90 daga frá aðgerð og 30 daga dánarhlutfall var pví $0 \%$.

Einn sjúklingur fékk lyfja- og geislameðferð fyrir aðgerð en í 8 tilvikum var gefin geislameðferð eftir aðgerð, par af hjá einum einstaklingi sem einnig fékk lyfjameðferð. Annar sjúklingur hóf geislameðferð en gat ekki lokið henni vegna bágs líkamlegs ástands eftir skurðaðgerð. Í öðru tilfelli var sjúklingi eingöngu gefin lyfjameðferð eftir aðgerð.

Tíu sjúklingar reyndust hafa hreinar skurðbrúnir (R0) við smásjárskoðun á sneiðum sem teknar voru úr peim hluta lungans sem var fjarlægður, en í tveimur tilfellum tókst ekki að fjarlægja allan æxlisvefinn (R2). Níu sjúklingar (75\%) greindust síðar með endurtekið krabbamein, par af fjórir með staðbundinn sjúkdóm, en fjórir höfðu dreifðan sjúkdóm, meðal annars meinvörp til heila, beina eða ásgarnar. Einn sjúklingur greindist samtímis með staðbundinn og dreifðan sjúkdóm. Tveir sjúklingar fengu geislameðferð eftir endurkomu æxlis og annar sjúklingur gekkst undir enduraðgerð premur árum eftir upphaflegu aðgerðina vegna meinvarpa í garnahengju ásgarnar (jejunum) frá Pancoast-æxlinu. Auk pess greindist einn sjúklingur við krufningu með sarkmein í rifi aðlægt brjóstholsskurði sem rakið var til geislameðferðar eftir aðgerð.

Við lok rannsóknarinnar voru 10 sjúklingar látnir, par af 7 úr sjúkdómnum. Fimm ára heildarlifun var 33\% og var miðgildi lifunar 27,5 mánuðir (bil: 4-181). Lifun peirra sem gengust undir miðmætisspeglun var 16, 68 og 181 mánuður.

\section{Umræður}

Árlega greinast um 160 einstaklingar hér á landi með lungnakrabbamein. ${ }^{28}$ Helsta læknandi meðferðin er skurðaðgerð, en aðgerð á fyrst og fremst við hjá sjúklingum með lungnakrabbamein af ekki smáfrumugerð á stigum I/II og í völdum tilfellum á stigi IIIA. ${ }^{17,20}$ Pessi rannsókn beindist sérstaklega að skurðmeðferð við Pancoast-æxlum á 20 ára tímabili á Íslandi. Niðurstöður sýna að tíðni alvarlegra fylgikvilla var lág (8\%) og enginn sjúklingur lést innan 30 daga. Einnig voru skurðbrúnir hreinar í 83\% tilfella sem er sambærilegt við erlendar rannsóknir.9, 10, 12-14, 18

Prátt fyrir góðan skammtímaárangur reyndust langtímahorfur sjúklinganna lakari (33\% 5 ára lifun) en í nýlegum erlendum rannsóknum, par sem pær hafa verið á bilinu 44-59\%.9, 10, 12, 14, 18 Níu sjúk- 
lingar (75\%) greindust með endurtekið krabbamein, par af 5 með staðbundna endurkomu (42\%). Petta er hærri tíðni endurkomu en í nýlegum rannsóknum par sem hún er oftast á bilinu 10-20\%.7, 9, 10, 12-14, 18 Taka verður tillit til pess að rannsókn okkar tekur til 20 ára tímabils og gera má ráð fyrir að stigun hafi verið ófullkomin á fyrri hluta rannsóknartímabilsins, til dæmis voru eitlar í miðmæti oft ekki rannsakaðir með miðmætisspeglun. Á undanförnum árum hefur stigun fyrir aðgerð verið bætt með aukinni áherslu á miðmætisspeglun en einnig berkjuómspeglun og tilkomu jáeindaskönnunar.6, 22, 27 Pannig er unnt að velja betur pá sjúklinga sem sannarlega eiga að gangast undir skurðaðgerð með lækningu að markmiði. Einnig er hugsanlegt að draga megi úr endurkomutíðni pessara æxla, sérstaklega staðbundinni endurkomu, með pví að gefa sampætta krabbameinslyfjameðferð og geislameðferð fyrir aðgerð, eins og mælt er með í alpjóðlegum klínískum leiðbeiningum..$^{21}$ Einnig hefur reynst vel að gefa sampætta meðferð eftir aðgerð..$^{10}$

Pótt langtímalífshorfur sjúklinga í pessari rannsókn hafi verið lakari en í nýlegum erlendum rannsóknum, verður að hafa í huga að flestar peirra eru afturskyggnar og byggja á litlu sjúklingapýði líkt og í okkar rannsókn. Pví miður eru ekki til neinar framskyggnar slembirannsóknir sem bera sérstaklega saman árangur mismunandi meðferðarúrræða við Pancoast-æxlum. ${ }^{16}$ Einnig verður að hafa í huga hvernig sjúklingar voru valdir í peim rannsóknum sem við berum okkur saman við, en oftast er um að ræða sjúklinga með lágt stigaðan sjúkdóm og hátt virkniskor. ${ }^{16}$ Okkar rannsókn náði aðeins til 12 sjúklinga sem voru skornir af 5 læknum á tveggja áratuga tímabili. Leiða má líkur að pví að reynsla skurðlækna við jafn flóknar aðgerðir hafi áhrif á árangur peirra, án pess að hægt væri að sýna fram á pað með okkar gögnum. Pví verður að gera fyrirvara við beinan samanburð á okkar niðurstöðum og peirra rannsókna sem pegar liggja fyrir.

Meirihluti sjúklinganna var með verki við greiningu (8/12), annaðhvort í öxl (5/12) eða í brjóstkassa (3/12), sem er svipað hlutfall og í öðrum rannsóknum.9, 26 Enginn sjúklingur reyndist vera með Horners-heilkenni, rýrnun á griplim eða bjúg á handlegg við greiningu. Pessi einkenni endurspegla oft langt genginn sjúkdóm vegna ífarandi vaxtar og skurðmeðferð pví síður möguleg. ${ }^{1}$ Athygli vekur hversu margir sjúklingar voru með hósta (6/12), megrun (5/12) og mæði (4/12) við greiningu, sem er hærra en í öðrum sambærilegum rannsóknum. ${ }^{9,14,26}$ Petta einkennamynstur gæti að einhverju leyti skýrst af pví að priðjungur sjúklinganna

\section{Heimildir}

Kanner R, Martini N, Foley K. Incidence of pain and other clinical manifestations of superior pulmonary sulcus (Pancoast) tumors. Adv Pain Res Ther 1982; 4: 27-39.

2. Van Houtte P, Maclennan I, Poulter C, Rubin P. External radiation in the management of superior sulcus tumor. Cancer 1984; 54: 223-7.

3. Ginsberg RJ, Martini N, Zaman M, Armstrong JG, Bains MS, Burt ME, et al. Influence of surgical resection and brachytherapy in the management of superior sulcus tumor. Ann Thor Surg 1994; 57: 1440-5.

4. Pancoast HK. Importance of careful roentgen-ray investigations of apical chest tumors. J Am Med Ass 1924; 83: 1407-11.

5. Shen KR, Meyers BF, Larner JM, Jones DR. Special Treatment Issues in Lung CancerACCP Evidence-Based Clinical Practice Guidelines. CHEST J 2007; 132(3_suppl): 290S-305S.

6. Detterbeck FC, Boffa DJ, Tanoue LT. The new lung cancer staging system. CHEST J 2009; 136: 260-71.
(4/12) hafði sögu um langvinna lungnateppu. Í okkar rannsókn var Pancoast-heilkenni ekki forsenda pess að lungnakrabbamein væri skilgreint sem Pancoast-æxli og er pað í samræmi við skilgreiningu bandarísku ACCP-samtakanna. ${ }^{21}$

Ađeins einn sjúklingur í rannsókninni fékk alvarlegan fylgikvilla (8\%) í tengslum við aðgerð, en í pví tilviki purfti að breyta blaðnámi í lungnabrottnám vegna mikillar blæðingar (> 1 L). Pessi tíðni alvarlegra fylgikvilla er lág samanborið við erlendar rannsóknir par sem hún hefur verið á bilinu 9-17\%. 9, 13, 14, 18 Pó verður að hafa í huga að sjúklingar í okkar rannsókn voru fáir og prósentutölur pví ónákvæmur mælikvarði á árangur. Engu að síður er athyglisvert að svipað hlutfall alvarlegra fylgikvilla sást í stærri íslenskri rannsókn á árangri blaðnáms við lungnakrabbameini, eða $7,5 \%{ }^{23}$ Tíðni minniháttar fylgikvilla reyndist hins vegar há (75\%) samanborið við aðrar rannsóknir (18-47\%), 2, 10, 24 og voru loftleki (5/12) og lungnabólga (2/12) efst á blaði. Prjátíu daga dánarhlutfall í pessari rannsókn mældist $0 \%$, en í sambærilegum rannsóknum hefur pað mælst frá 0 til 6,9\%.

Helsti styrkleiki pessarar rannsóknar er sá að hún tekur til allra peirra sjúklinga sem greindust með Pancoast-krabbamein og voru meðhöndlaðir með lungnaskurðaðgerð hjá heilli pjóð um tveggja áratuga skeið. Allir sjúklingarnir voru meðhöndlaðir á sama sjúkrahúsi. Einnig var leitað að sjúklingum í tveimur aðskildum skrám, sem minnkar líkur á pví að einhver tilfelli hafi gleymst. Hafa verður í huga að rannsóknin náði aðeins til sjúklinga sem gengust undir skurðaðgerð en ekki allra sem fengu greininguna Pancoast-æxli. Pessi rannsókn endurspeglar pví ekki einkenni allra sjúklinga með Pancoast-æxli sem greindust á rannsóknartímabilinu. Rannsóknin var afturskyggn en slíkar rannsóknir geta verið takmarkaðar hvað varðar mat á einkennum og fylgikvillum, enda einungis stuðst við upplýsingar úr sjúkraskrám. Einnig er sjúklingapýði rannsóknarinnar lítið, sem minnkar tölfræðilegt vægi hennar.

Árangur skurðaðgerða og skammtímahorfur sjúklinga með Pancoast-krabbamein er góður hérlendis. Langtímahorfur sjúklinga í pessari rannsókn voru hins vegar lakari en í nýlegum erlendum rannsóknum og tíðni staðbundinnar endurkomu há. Hér á landi fékk aðeins einn sjúklingur sampætta geisla- og lyfjameðferð fyrir aðgerð og er spurningin hvort fleiri sjúklingar ættu að fá slíka meðferð til að fækka endurteknum krabbameinum og bæta horfur.

Pakkir fær Gunnhildur Jóhannesdóttir ritari á skurðsviði Landspítala fyrir aðstoð við leit að sjúkraskrám.
7. Bruzzi JF, Komaki R, Walsh GL, Truong MT, Gladish GW, Munden RF, et al. Imaging of Non-Small Cell Lung Cancer of the Superior Sulcus: Part 1: Anatomy, Clinical Manifestations, and Management 1. Radiographics. 2008; 28: 551-60.

8. Peedell C, Dunning J, Bapusamy A. Is There a Standard of Care for the Radical Management of Non-small Cell Lung Cancer Involving the Apical Chest Wall (Pancoast Tumours)? Clin Oncol 2010; 22: 334-46.

9. Rusch VW. Management of Pancoast tumours. Lancet Oncol 2006; 7: 997-1005.

10. Rusch VW, Giroux DJ, Kraut MJ, Crowley J, Hazuka M, Winton $\mathrm{T}$, et al. Induction chemoradiation and surgical resection for superior sulcus non-small-cell lung carcinomas: long-term results of Southwest Oncology Group Trial 9416 (Intergroup Trial 0160). J Clin Oncol 2007; 25: 313-8.
11. Kunitoh $\mathrm{H}$, Kato $\mathrm{H}$, Tsuboi $M$, Shibata $T$, Asamura $\mathrm{H}$, Ichonose $\mathrm{Y}$, et al. Phase II Trial of Preoperative Chemoradiotherapy Followed by Surgical Resection in Patients With Superior Sulcus Non-Small-Cell Lung Cancers: Report of Japan Clinical Oncology Group Trial 9806. J Clin Oncol 2008; 26: 644-9.

12. Attar S, Krasna MJ, Sonett JR, Hankins JR, Slawson RG, Suter CM, et al. Superior sulcus (Pancoast) tumor: experience with 105 patients. Ann Thorac Surg 1998; 66: 193-8.

13. Goldberg M, Gupta D, Sasson AR, Movsas B, Langer CI Hanlon AL, et al. The Surgical Management of Superior Sulcus Tumors: A Retrospective Review With Long-Term Follow-Up. Ann Thorac Surg 2005; 79: 1174-9.

14. Tamura M, Hoda MA, Klepetko W. Current treatment paradigms of superior sulcus tumours. Eur J CardioThorac Surg 2009; 36: 747-53

15. Detterbeck FC. Changes in the treatment of Pancoast tumors. Ann Thorac Surg 2003; 75: 1990-7.

16. www.krabbameinsskra.is 
17. Scott WJ, Howington J, Feigenberg S, Movsas B, Pisters K. Treatment of non-small cell lung cancer stage I and stage II: ACCP evidence-based clinical practice guidelines (2nd edition). Chest 2007; 132(3 Suppl): 234S-42S.

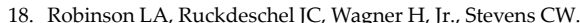
Treatment of non-small cell lung cancer-stage IIIA: ACCP evidence-based clinical practice guidelines (2nd edition). Chest 2007; 132(3 Suppl): 243S-65S.

19. Kwong KF, Edelman MJ, Suntharalingam M, Cooper LB, Gamliel Z, Burrows W, et al. High-dose radiotherapy in trimodality treatment of Pancoast tumors results in high pathologic complete response rates and excellent longterm survival. J Thorac Cardiovasc Surg 2005; 129: 1250-7.

20. Marra A, Eberhardt W, Pöttgen C, Theegarten D, Korfee $\mathrm{S}$, Gauler $\mathrm{T}$, et al. Induction chemotherapy, concurrent chemoradiation and surgery for Pancoast tumour. Eur Resp J 2007; 29: 117-26. 5.
21. Gomez DR, Cox JD, Roth JA, Allen PK, Wei X, Mehran RI, et al. A prospective phase 2 study of surgery followed by chemotherapy and radiation for superior sulcus tumors. Cancer 2012; 118: 444-51.

22. Fischer S, Darling G, Pierre AF, Sun A, Leighl N, Waddell $\mathrm{TK}$, et al. Induction chemoradiation therapy followed by surgical resection for non-small cell lung cancer (NSCLC) invading the thoracic inlet. Eur J Cardio-Thorac Surg 2008; 33: 1129-34.

23. Silvestri GA, Gould MK, Margolis ML, Tanoue LT, McCrory D, Toloza E, et al. Noninvasive staging of nonsmall cell lung cancer: Accp evidenced-based clinical practice guidelines (2nd edition). Chest 2007; 132(3_suppl): 178S-201S

24. Detterbeck FC, Jantz MA, Wallace M, Vansteenkiste I, Silvestri GA. Invasive mediastinal staging of lung cancer: Accp evidence-based clinical practice guidelines (2nd edition). Chest 2007;132(3_suppl):202S-20S.
25. Wallace MB, Pascual JS, Raimondo M, et al. MInimally invasive endoscopic staging of suspected lung cancer. JAMA 2008; 299: 540-6.

26. Skúladóttir R, Óskarsdóttir GN, Ísaksson HJ, Jónsson $\mathrm{S}$, Porsteinsson $\mathrm{H}$, Guðbjartsson T. Fylgikvillar blaðnámsaðgerða við lungnakrabbameini á Íslandi 1999-2008. Læknablaðið 2010; 96: 243-9.

27. Brunelli A, Monteverde M, Borri A, Salati M, Marasco RD, Fianchini A. Predictors of prolonged air leak after pulmonary lobectomy. Ann Thorac Surg 2004; 77: 1205-10.

28. Stolz AJ, Schützner J, Lischke R, Simonek J, Pafko P. Predictors of prolonged air leak following pulmonary lobectomy. Eur J Cardio-ThoraC Surg 2005; 27: 334-6.

\title{
ENGLISH SUMMARY
}

\section{Outcome of surgical treatment for Pancoast lung carcinoma in Iceland}

\author{
Bjorn Mar Fridriksson', Steinn Jonsson², Gudrun Nina Oskarsdottir ${ }^{1}$, Andri Wilberg Orrason'1, Helgi J. Isaksson ${ }^{3}$, Tomas Gudbjartsson ${ }^{1,4}$
}

Objective: Pancoast tumors are lung carcinomas that invade the apical chest wall and surrounding structures. Treatment is complex and often involves surgery together with radio- and chemotherapy. We studied the outcome of surgical resection for Pancoast tumors in Iceland.

Materials and Methods: A retrospective study including all patients that underwent resection of a Pancoast tumor with curative intent in Iceland in the years 1991-2010. Data on symptoms, complications, TNM-stage, relapse and survival were analyzed.

Results: Twelve patients were operated on; 7 on the right lung. Shoulde pain $(n=5)$ and/or chest pain $(n=3)$, cough $(n=6)$ and weight loss $(n=5)$ were the most common presenting symptoms. Adenocarcinoma $(n=5)$ and squamous cell carcinoma $(n=4)$ were the most frequent histological types. Average tumor size was $5,9 \mathrm{~cm}$ (range: 2,8-15). Five cases were stage IIB and 7 stage IIIA according to operative staging. In 10 cases
(83\%) the surgical margins were free of tumor. All patients survived surgery and only one patient suffered a major operative complication, an intraoperative bleeding. In one case induction chemo-radiation prior to surgery was administrated, and 8 patients received postoperative radiotherapy. Recurrent disease was diagnosed in 9 patients; four had local or regional recurrence, four had distant metastases and one patient was diagnosed with both local and distant recurrences simultaneously. Survival at 5 years was $33 \%$ and median survival was 27,5 months (range: 4-181).

Conclusions: Operative and short-term outcomes for patients with Pancoast tumors in Iceland are excellent. However, long-term outcomes are not as favorable and recurrence rate is high compared to other studies, possibly due to incomplete preoperative staging and less use of chemo-radiation therapy prior to surgery among these patients.

${ }^{1}$ Faculty of Medicine, University of Iceland, Departments of ${ }^{2}$ Pulmonology, ${ }^{3}$ Pathology and ${ }^{4}$ Cardiothoracic Surgery, Landspitali University Hospital. Key words: Pancoast tumor, non-small cell lung cancer, treatment, outcome, relapse, survival.

Correspondence: Tomas Gudbjartsson, tomasgud@landspitali.is

\section{Spiriva Respimat 2,5 míkrógrömm, innöndunarlausn}

Boehringer Ingelheim International GmbH. ATC flokkur: R03BB04. Samantekt á eiginleikum lyfs - styttur texti SPC.

Heiti lyfs: Spiriva Respimat 2,5 míkrógrömm, innöndunarlausn. Virk innihaldsefni og styrkleikar: Hver gefin úđun er 2,5 míkrógrömm tiótrópíum (2 úđanir eru einn lyfjaskammtur), sem samsvarar 3,124 míkrógrömmum af tiótrópíumbrómíđeinhýdrati. Hver gefin úđun er sá skammtur sem farið hefur í gegnum munnstykkið og sjúklingurinn fær. Ábendingar: Langvinn lungnateppa (LLT):

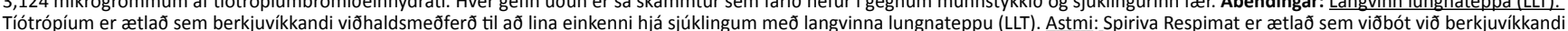
viðhaldsmeðferð hjá fullorðnum sjúklingum með astma sem fá viððhaldsmeđferð með samsetningu af innöndunarstera (>800 míkróg budesonid/sólarhring eđa jafngildum innöndunarstera) o langverkandi $\beta_{2}$-örva og sem hafa fengið eina eđa fleiri alvarlegar versnanir undangengið ár. Skammtar og lyfjagjöf: Skammtar: Lyfið er eingöngu ætlađ til innöndunar. Rörlykkjuna má ađeins setja í og nota með Respimat innöndunartæki. Tvær úđanir úr Respimat innöndunartæki jafngilda einum lyfjaskammti. Ráđlagđur skammtur fyrir fullorðna er 5 míkrógrömm af tíotrópíum, gefið međ tveimur úđunum úr Respimat innöndunartækinu, einu sinni á sólarhring, alltaf á sama tíma sólarhringsins. Ekki má nota stærri skammta en ráđlagđir eru. Í astmameđferđ mun fullur ávinningur lyfsins koma i ljós eftir nokkra skammta. Sérstakir hópar: Aldrađir sjúklingar geta notađ tiótrópíumbrómíð í ráđlögđum skömmtum. Sjúklingar međ skerta nýrnastarfsemi mega nota tiótrópíumbrómíð í ráđlögđum skömmtum. Sjúklingar með miðlungs eđa alvarlega skerta nýrnastarfsemi (kreatínínúthreinsun $\leq 50 \mathrm{ml} / \mathrm{mín}$.). Sjúklingar með skerta lifrastarfsemi mega nota tiótrópíumbrómíđ í ráđlögđum skömmtum. Börn: Langvinn lungnateppa (LLT): Notkun Spiriva Respimat á ekki við hjá börnum og unglingum undir 18 ára aldri. Slímseigjusjúkdómur (cystic fibrosis):Ekki hefur verið sýnt fram á verkun og öryggi Spiriva Respimat. Astmi: Ekki hefur enn verið sýnt fram á verkun og öryggi Spiriva Respimat hjá börnum og unglingum. Lyfiagiöf: Til ađ̃ tryggja rétta lyfjagjöf skal læknir eđa faglærđur heilbrigðisstarfsmađur sýna sjúklingi hvernig nota eigi úđatækið. Frábendingar: Spiriva Respimat er ekki ætlađ sjúklingum með ofnæmi fyrir tiótrópíumbrómíđi, atrópíni eđa afleiđum bess, t.d. ipatrópíum, oxítrópíum eđa einhverju hjálparefnanna. Upplýsingar um aukaverkanir, milliverkanir, varnađarorõ og önnur mikilvæg atriđi má nálgast í sérlyfjaskrá ? www.serlyfjaskra.is. Markađsleyfishafi: Boehringer Ingelheim International GmbH, Binger Strasse 173, D-55216 Ingelheim am Rhein, pýskaland. Nánari upplýsingar um lyfio fást hjá umbođsaðila á íslandi sem er: Vistor hf., Hörgatúni 2, 210 Garđabæ, Sími: 535-7000. Dagsetning síđustu sampykktar SPC sem pessi stytti texti byggir á: 07.01 .2015 . Ath. textinn er styttur. fást hjá umbođsađ̃ila á Íslandi sem er: Vistor hf., Hörgatúni 2, 210 Garđabæ, Sími: 535-7000. Dagsetning síđustu sampykkt 9.208 kr.Afgreiðslutilhögun: $R$ einungis afgreitt međ lyfseđli.Greiðslupátttaka sjúkratrygginga: $G$ merkt sjá nánar á www.lgn.is

Striverdi Respimat, 2,5 míkrógrömm, innöndunarlausn.

Boehringer Ingelheim International GmbH. ATC flokkur: R03AC19. Samantekt á eiginleikum lyfs - styttur texti SPC.

Heiti lyfs: Striverdi Respimat, 2,5 míkrógrömm, innöndunarlausn. Virk innihaldsefni og styrkleikar: Gefinn skammtur er 2,5 míkrógrömm af olodateroli (sem hýdróklóríđ) í hvert sinn sem úđađ er. Gefinn skammtur er sá skammtur sem fer i gegnum munnstykkið og nær til sjúklingsins. Abendingar: Striverdi Respimat er ætlað sem berkjuvíkkandi viðhaldsmeðferð hjá sjúklingum með langvinn lungnateppu (LLT). Skammtar og lyfjagjöf: Skammtar: Lyfið er eingöngu ætlað til innöndunar. Rörlykjuna má aðeins setja í og nota með Respimat innöndunartæki. Tvær úđanir úr Respimat innöndunartæki jafngilda einum lyfjaskammti. Fullorđnir: Ráđlagđur skammtur er 5 míkrógrömm af olodateroli, gefið međ tveimur úđunum úr Respimat innöndunartækinu, einu sinni á sólarhring, alltaf á sama tíma sólarhringsins. Ekki má nota stærri skammt en ráđlagđur er. Aldrađir sjúklingar: Aldrađir sjúklingar geta notađ Striverdi Respimat samkvæmt ráđlögđum skammti. Skert lifrarstarfsemi: ámán Sjúklingar međ væga eđa miðlungsmikla skerđingu á lifrarstarfsemi mega nota Striverdi Respimat samkvæmt ráđlögđum skömmtum. Engar upplýsingar liggja fyrir um notkun Striverdi Respimat hjá juúklingum međ verulega skerta lifrarstarfsemi. Skert nýrnastarfsemi: Sjúklingar međ skerta nýrnastarfsemi mega nota Striverdi Respimat samkvæmt ráđlögđum skammti. Takmörkuð reynsla er af notkun Striverdi Respimat hjá sjúklingum međ verulega skerta nyrnastarfsemi. Börn: Notkun Striverdi Respimat á ekki við hjá börnum og unglingum (undir 18 ára aldri). Lyfjagjöf: Til ađ tryggja rétta gjöf lyfsins skal læknir eđa faglærđur heilbrigðisstarfsmađur sýna sjúklingi hvernig nota eigi innöndunartækið. Frábendingar: Striverdi Respimat er ekki ætlađ sjúklingum með ofnæmi fyrir olodateroli eđa einhverju hjálparefnanna. Upplýsingar um aukaverkanir, milliverkanir, varnađarorđ og önnur mikilvæg atriđi má nálgast í sérlyfjaskrá - www.serlyfjaskra.is. Markađsleyfishafi: Boehringer In elheim International GmbH, Binger Strasse 173, D-55216 Ingelheim am Rhein, pýskaland. Nánari upplýsingar um lyfiơ fást hjá umbođsađila á Íslandi sem er: Vistor hf., Hörgatúni 2, 210 Garđabæ, Sími: 535-7000. Dagsetning síđustu sampykktar SPC sem pessi stytti texti byggir á: 10. október 2013. Ath. textinn er styttur. Sjá nánari upplýsingar í sérlyfjaskrá - www.serlyfjaskra.is. Pakkningar og verð ( Júní 2015): $2.5 \mathrm{mcg} 60$ skammtar 7.338 kr. Afgreiðslutilhögun: R einungis afgreitt gegn lyfseđli. Greiđslupátttaka sjúkratrygginga: $G$ merkt sjá nánar á www.lgn.is 